\title{
Protein profile of the seminal plasma of collared peccaries (Pecari tajacu Linnaeus, 1758)
}

\author{
E A A Santos, P C Sousa, J A M Martins ${ }^{1}$, R A Moreira², A C O Monteiro-Moreira², \\ F B M B Moreno ${ }^{2}$, M F Oliveira, A A Moura ${ }^{1}$ and A R Silva \\ Laboratory of Animal Germplasm Conservation, Federal University of the Semi-arid, BR 110, Km 47, Bairro Costa e \\ Silva, 59625-900 Mossoró, Rio Grande do Norte, Brazil, ' Department of Animal Science, Federal University of Ceará, \\ 60021-970 Fortaleza, Brazil and ${ }^{2}$ School of Pharmacy, University of Fortaleza, 60811-905 Fortaleza, Brazil
}

Correspondence should be addressed to A R Silva; Email: legio2000@yahoo.com

\begin{abstract}
This study was conducted to characterize the major proteins of the peccary seminal plasma, based on the semen samples collected from nine adult and reproductively sound animals. Our approach included the use of two-dimensional electrophoresis followed by Coomassie blue staining and analysis of polypeptide maps with PDQuest Software (Bio-Rad). Proteins were identified by tandem mass spectrometry (LC-MS/MS). We detected 179 protein spots per gel and 98 spots were identified by mass spectrometry, corresponding to 23 different proteins. The combined intensity of those spots accounted for $56.2 \pm 6 \%$ of the intensities of all spots and $60.9 \%$ of the intensities of spots presented in every protein map. Protein spots identified as clusterin represented $19.7 \pm 8.3 \%$ of the integrated optical densities of all spots detected in the seminal plasma maps. There was a negative association $(r=-0.87 ; P<0.05)$ between the intensity of a clusterin spot and the percentage of sperm with functional membrane. Spermadhesin porcine seminal plasma protein 1 and bodhesin 2 comprised $5.4 \pm 1.9$ and $8.8 \pm 3.9 \%$ of the total intensity of all spots respectively. Many proteins appeared in a polymorphic pattern, such as clusterin (27 spots), epididymal secretory glutathione peroxidase (ten spots), inter- $\alpha$-trypsin inhibitor (12 spots), and IgG-binding protein (ten spots), among others. In conclusion, we presently describe the major seminal plasma proteome of the peccary, which exhibits a distinct high expression of clusterin isoforms. Knowledge of wild species reproductive biology is crucial for an understanding of their survival strategies and adaptation in a changing environment.

Reproduction (2014) 147 753-764
\end{abstract}

\section{Introduction}

For decades, native American communities have used wildlife as a source of animal protein. Despite prohibitive laws, poaching is still occurring worldwide and this has been a major problem in populated areas. To overcome this situation, at least partially, adaptation of wild species to captivity is proving to be a promising solution. The collared peccary (Pecari tajacu Linnaeus, 1758) is a clear example as it constitutes a potential resource for commercial exploitation, production of meat, and leather. Moreover, the International Union for Conservation of Nature (IUCN) classifies the peccaries as a least concerned species but emphasizes that the population is disappearing in some regions of their natural habitats (IUCN, http://www.iucn.org/about/ work/programmes/species/our_work/the_iucn_red_list/, access in: 18th September 2013).

Knowledge on the reproductive aspects of collared peccaries is of crucial importance for the development of appropriate management practices (Mayor et al. 2007).
Several researches have been demonstrating important aspects of their reproduction. For instance, the peccary spermatogenesis presents a meiotic index of 1:2.7, which is very similar to that of swine, a closely related domestic species (Costa et al. 2004). As in the swine, the peccary ejaculate is composed of three fractions: i) clear and colorless, ii) rich in spermatozoa, and iii) the jelly fraction (Hellgren et al. 1989). Fractions that constitute the seminal plasma are mainly originated from the prostate, seminal vesicles, and bulbourethral glands (Garcia et al. 2000).

In the domestic swine, recent studies have been focused on origin and function of seminal plasma proteins (Huang et al. 2000). Two spermadhesins presenting $26 \mathrm{kDa}(\mathrm{pl} \mathrm{6.2)}$ ) and $55 \mathrm{kDa}(\mathrm{pl} 4.5$ ) were identified as potential markers for fertility in this species, as its presence is associated with high prolificity rates (Flowers \& Turner, 2001). In addition, the $26 \mathrm{kDa}$ protein was related to better sperm membrane integrity after freezingthawing processes (Bianchi et al. 2008). The characterization of proteins present in the seminal plasma may 
provide essential information for identification of molecular determinants of fertility. It would contribute for the knowledge on reproductive aspects of the peccaries, in which there is still a lack of such information. This knowledge would be useful for the selection of the more appropriate stud males for use in natural reproduction and for the formation of germplasm banks. Therefore, this study was conducted to characterize the major proteins of the seminal plasma and their associations with semen characteristics in collared peccaries.

\section{Materials and methods}

\section{Animals}

All experimental protocols and animal care procedures were approved by the Ethics Committee of the Federal University of the Semi-arid (UFERSA) for handling animals (process no. 23 091.0254/11-88). Collared peccaries (P. tajacu) used in the experiment were provided by the Center for Multiplication of Wild Animals (UFERSA), located in the northeast of Brazil (Mossoró, RN, Brazil; $5^{\circ} 10^{\prime} \mathrm{S}$ and $37^{\circ} 10^{\prime} \mathrm{W}$ ). The climate of this region is typically semi-arid, with an average annual temperature of $27^{\circ} \mathrm{C}$. Nine healthy and sexually mature males aged $21 \pm 1$ months and each weighing $20.1 \pm 0.1 \mathrm{~kg}$ were used. They were isolated from females 6 months before the beginning of the study and maintained under a 12-h natural photoperiod throughout the research. They were maintained in paddocks $(20 \times 3 \mathrm{~m})$, with a covered area $(3 \times 3 \mathrm{~m})$ and fed sow food and fruits, with free access to water.

\section{Semen collection}

For semen collection, males were physically restrained by a capture net and then anesthetized by i.v. administration of propofol (Propovan, Cristalia, Fortaleza, Brazil) on a dose of $5 \mathrm{mg} / \mathrm{kg}$ of body weight, as previously described (Souza et al. 2009). Semen was collected with the aid of an electroejaculator (Autojac, Neovet, Campinas, SP, Brazil) connected to a $12 \mathrm{~V}$ source (Castelo et al. 2010). The stimulatory cycle comprised ten stimuli in each voltage, starting from $5 \mathrm{~V}$, followed by a voltage increase in steps of $1 \mathrm{~V}$, up to $12 \mathrm{~V}$. Each electrical stimulus lasted $3 \mathrm{~s}$, with intermittent breaks of $2 \mathrm{~s}$. The stimuli cycles were maintained for $10 \mathrm{~min}$ from the beginning of the procedure. The dimension of the electroejaculator probe was $15 \times 1.3 \mathrm{~cm}$, and $12 \mathrm{~cm}$ of the probe was inserted into the animal rectum. Semen was collected in plastic tubes and mixed with a cocktail of protease inhibitors (Sigma-Aldrich, catalog no. P8340). Aliquots of semen samples were taken for semen analysis and the remaining samples, centrifuged at $700 \mathrm{~g}$ for $10 \mathrm{~min}$, were transferred to clean tubes and stored at $-20^{\circ} \mathrm{C}$ until further analysis.

\section{Semen evaluation}

The volume of semen was measured using micropipettes and we recorded the aspect of the ejaculates. The percentage of motile sperm and sperm vigor was immediately assessed using light microscopy at $100 \times$ and $400 \times$ magnification .
For determination of sperm vigor, we used a $0-5$ scale, where 0 was given to sperm with no movement and 5 characterized the maximum sperm progressive forward movement. Bromophenol blue-stained smears were prepared using $5 \mu \mathrm{l}$ semen for evaluation of sperm morphology under light microscopy $(1000 \times)$ and viability $(400 \times)$, counting 200 cells/slide. Sperm concentration was determined using a Neubauer counting chamber. Sperm functional integrity was analyzed by the hypoosmotic swelling test, using distilled water as the hypo-osmotic solution (Castelo et al. 2010), counting 200 cells.

\section{Determination of seminal plasma protein profile}

Two-dimensional gel electrophoresis

For two-dimensional (2D) electrophoresis, seminal plasma samples from nine individuals were individually thawed at room temperature and centrifuged at $10000 \mathrm{~g}$ for $1 \mathrm{~h}$ at $4{ }^{\circ} \mathrm{C}$ (Moura et al. 2006). Samples containing $400 \mu \mathrm{g}$ protein (Bradford 1976) were mixed with re-hydration buffer (7 M urea, $2 \mathrm{M}$ thiourea, $0.5 \%$ CHAPS, $0.5 \%$ immobilized $\mathrm{pH}$ gradient (IPG) buffer, $\mathrm{pH} 4-7,65 \mathrm{mM}$ dithiothreitol (DTT), and traces of bromophenol blue) in an amount enough to make $250 \mu \mathrm{l}$ (Souza et al. 2012). Then, the mixture was incubated with $13 \mathrm{~cm}$ IPG strips in the $\mathrm{pH}$ range of 4-7 (GE Life Sciences, Piscataway, NJ, USA) and allowed to re-hydrate for $20 \mathrm{~h}$. Isoelectric focusing was performed in an Ettan IPGphor 3 apparatus (GE Life Sciences), at $100 \mathrm{~V}$ for $2 \mathrm{~h}, 500 \mathrm{~V}$ for $1 \mathrm{~h}$, $1000 \mathrm{~V}$ for $30 \mathrm{~min}, 5000 \mathrm{~V}$ for $2 \mathrm{~h}$, and $8000 \mathrm{~V}$ for $1 \mathrm{~h}$, in a total of $24000 \mathrm{Vh}$. After focusing, seminal plasma proteins were equilibrated in equilibration buffer I (6 M urea, $50 \mathrm{mM}$ Tris$\mathrm{HCl}, \mathrm{pH} 8.8,29.3 \%$ glycerol, 2\% SDS, and 1\% DTT) for $15 \mathrm{~min}$ and re-equilibrated thereafter for an additional $15 \mathrm{~min}$ in equilibration buffer II (similar to equilibration buffer I, but containing $2.5 \%$ iodoacetamide instead of DTT). After equilibration, IPG strips were placed on the top of SDS-PAGE gels, containing a homogeneous concentration of acrylamide (12.5\%). Standards from 97 to $14 \mathrm{kDa}$ (Sigma Chemical Co.) were used and gels were run in an SE 600 Ruby apparatus $(12.5 \%$ T/2.6\% C, $250 \mathrm{~V}$, and $25 \mathrm{~mA} /$ gel) for $\sim 5 \mathrm{~h}$. Reagents for electrophoresis were purchased from GE Life Sciences or Sigma-Aldrich.

Gels were stained by colloidal Coomassie blue (Souza et al. 2012), scanned at 300 dpi (ImageScanner II; GE Life Sciences), and analyzed using PDQuest Software, version 7.3.0 (Bio-Rad Laboratories). For the set of nine seminal plasma protein maps, a master gel was generated by the software, based on a reference gel, which represented the best pattern of spots in all samples of the study. Additional spots consistently present in other gels were also added to the master and proteins in key regions of the gels were used as landmarks. Control of spot matches was done by checking each spot, in each gel, with the respective pattern in the master. Protein quantities in the gels were given as parts per million (ppm) of the total integrated optical density of the spots, according to PDQuest Software (Moura et al. 2007, 2010, Souza et al. 2012).

\section{Protein identification}

Proteins separated by 2D-PAGE were subjected to in-gel trypsin digestion as described elsewhere (Souza et al. 2012). 
Briefly, excised gel pieces were washed three times with $400 \mu \mathrm{l}$ of a solution containing ammonium bicarbonate $(25 \mathrm{mM})$ and acetonitrile (50\%), pH 8.0, to remove SDS and dye, dehydrated after two washes with $200 \mu \mathrm{l}$ of absolute acetonitrile, and completely dried under vacuum. Gel pieces were then incubated ( $\sim 20 \mathrm{~h})$ at $37^{\circ} \mathrm{C}$ with trypsin (166 ng/spot, Promega, catalog no. V5111). Peptides were then extracted from gel pieces by washing three times with $25 \mu$ of trifluoroacetic (5\%) in ammonium bicarbonate $(50 \mathrm{mM})$ and acetonitrile $(50 \%)$ for $30 \mathrm{~min}$. The extracts were dried under vacuum again and re-suspended in $10 \mu \mathrm{l}$ of injection buffer (95\% water, 5\% acetonitrile, and $0.1 \%$ formic acid). A piece of blank gel and a piece of albumin from the molecular weight marker were also digested and used as negative and positive controls respectively.

For tandem mass spectrometry (LC-MS/MS), the digested samples were injected using the nanoAcquity UPLC sample manager and the chromatographic separation was performed using a UPLC C18 column $(75 \mu \mathrm{m} \times 10 \mathrm{~cm})$ with a flow of $0.6 \mu \mathrm{l} / \mathrm{min}$ (Souza et al. 2012). The mass spectra were acquired in a Synapt G2 HDMS instrument (Waters Co., Milford, MA, USA) using a data-dependent acquisition, where the three top peaks were subjected to MS/MS. Mobile phases A and B consisted of $0.1 \%$ formic acid in water and $0.1 \%$ formic acid in acetonitrile respectively. The gradient conditions used were as follows: 0 min with $3 \%$ of B, increasing linearly to $30 \%$ B in 20 min, then it increased up to $70 \% \mathrm{~B}$ in $40 \mathrm{~min}$ where it remained until $50 \mathrm{~min}$ and in the next minute it was decreased to $3 \%$ of $\mathrm{B}$. The data were processed using Mascot Distiller (Matrix Science Ltd; www.matrixscience.com) and subjected to database search using Mascot Server 2.3, using mammalia as the taxon. The searches were made with the assumption that there was a maximum of one missed trypsin cleavage and that peptides were mono-isotopic and using partially oxidized methionine residues and completely carbamidomethylated cysteine residues. Peptide mass tolerance and fragment mass tolerance were initially set to \pm 0.1 Da respectively for MS/MS ion searching. However, candidate peptide IDs were only accepted if the $\mathrm{m} / \mathrm{z}$ values were observed within $0.1 \mathrm{Da}$ (typically $<0.05 \mathrm{Da}$ ) of the theoretical mass of the candidate ID, as determined when manually reviewing MASCOT search results.

\section{Gene ontology analysis}

Data from the seminal plasma protein list obtained after MASCOT search were analyzed using the Software for Researching Annotations of Proteins (STRAP), an open-source application, as previously reported (Souza et al. 2012). Gene ontology terms for biological process and molecular function were obtained from UniProtKB and EBI GOA databases. Gene ontology associated with peccary seminal plasma proteins was also compared with that of other species such as rams (Souza et al. 2012) and domestic boar (Sus scrofa; V R Cadavid, J M Martins \& A A Moura 2013, unpublished results). Comparisons were only made using gene ontology analyses that were previously conducted with the same software used in this study.

\section{Protein interaction analysis}

Analysis of known and predicted protein-protein interactions were run for clusterin using the open-access database-based online tool STRING (http://string-db.org), version 9.05. In this case, analyses were conducted assuming Bos taurus as the organism. In the evidence view, interactions were based in co-expression (black lines), databases (light blue), text-mining (yellow), and experimental (purple) data. In the action mode, interactions represent reaction (black lines), binding (blue), or catalysis (purple). Only proteins with a confidence score above 0.900 were selected for analysis.

\section{Statistical analyses}

The experiment followed a completely randomized design, where each animal was considered as a random factor. Semen parameters and spot intensities from protein maps were tested for normality, using the Shapiro-Wilk's test, and for

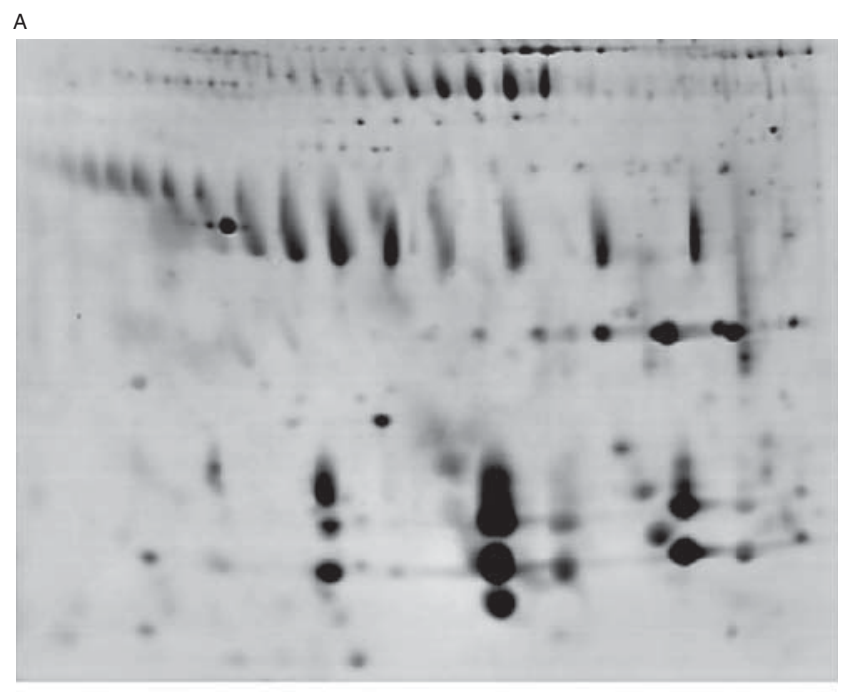

B

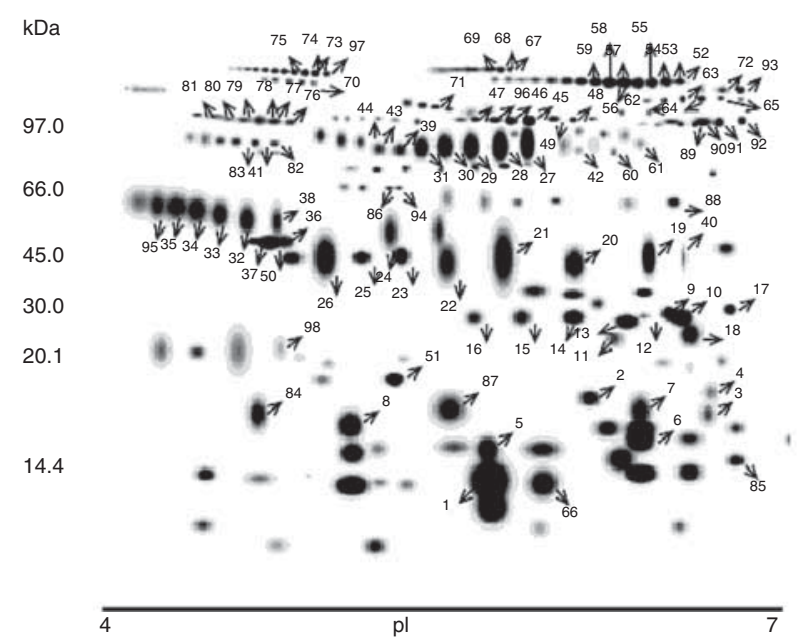

Figure 1 Seminal plasma proteins of adult Pecari tajacu. (A) Represents the map used as a reference for the match set. (B) Master gel generated by the PDQuest Software using gels from nine animals. Gels were stained with Commassie blue and proteins identified by mass spectrometry. Spot numbers refer to those in Table 1 and Supplementary Table 1. 
Table 1 Seminal plasma proteins of collared peccaries (Pecari tajacu) identified by two-dimensional electrophoresis and tandem mass spectrometry. Table includes spots detected in $13 \mathrm{~cm}$ gels, within the 4-7 pH range. Spot numbers refer to those in Fig. 1.

\begin{tabular}{|c|c|c|c|c|}
\hline Protein and spot numbers & $\begin{array}{c}\text { NCBI accession } \\
\text { number }\end{array}$ & $\begin{array}{l}\text { MS/MS protein } \\
\text { score }\end{array}$ & $\begin{array}{c}\text { Sequence } \\
\text { covered }(\%)\end{array}$ & $\begin{array}{l}\text { Relative quantity } \\
(\text { mean } \pm \text { s.D. } \%)\end{array}$ \\
\hline Bodhesin 2 & & & & $8.8 \pm 3.9$ \\
\hline Spot 01 & 121484235 & 92 & 27 & \\
\hline Epididymal secretory protein E1 & & & & $1.2 \pm 0.7$ \\
\hline Spot 02 & 47523496 & 121 & 28 & \\
\hline Spot 03 & 47523496 & 148 & 28 & \\
\hline Spot 04 & 47523496 & 125 & 28 & \\
\hline Spermadhesin PSP-1 & & & & $5.4 \pm 1.9$ \\
\hline Spot 05 & 108346 & 47 & 9 & \\
\hline Spot 06 & 108346 & 82 & 9 & \\
\hline Spot 07 & 108346 & 44 & 9 & \\
\hline Casein $\propto$ S1 & & & & $2.7 \pm 1.5$ \\
\hline Spot 08 & 30794348 & 43 & 5 & \\
\hline Epididymal secretory glutathione peroxidase & & & & $6.1 \pm 1$ \\
\hline Spot 09 & 47523090 & 75 & 19 & \\
\hline Spot 10 & 47523090 & 186 & 22 & \\
\hline Spot 11 & 47523090 & 95 & 24 & \\
\hline Spot 12 & 47523090 & 94 & 24 & \\
\hline Spot 13 & 47523090 & 116 & 19 & \\
\hline Spot 14 & 47523090 & 78 & 24 & \\
\hline Spot 15 & 47523090 & 81 & 19 & \\
\hline Spot 16 & 47523090 & 159 & 22 & \\
\hline Spot 17 & 47523090 & 128 & 17 & \\
\hline Spot 18 & 47523090 & 47 & 5 & \\
\hline Clusterin & & & & $19.74 \pm 8.32$ \\
\hline Spot 19 & 47522770 & 346 & 12 & \\
\hline Spot 20 & 47522770 & 220 & 8 & \\
\hline Spot 21 & 47522770 & 200 & 8 & \\
\hline Spot 22 & 47522770 & 160 & 8 & \\
\hline Spot 23 & 47522770 & 135 & 15 & \\
\hline Spot 24 & 47522770 & 152 & 8 & \\
\hline Spot 25 & 47522770 & 136 & 12 & \\
\hline Spot 26 & 47522770 & 94 & 10 & \\
\hline Spot 27 & 47522770 & 203 & 11 & \\
\hline Spot 28 & 47522770 & 189 & 11 & \\
\hline Spot 29 & 47522770 & 409 & 10 & \\
\hline Spot 30 & 47522770 & 465 & 14 & \\
\hline Spot 31 & 47522770 & 279 & 12 & \\
\hline Spot 32 & 47522770 & 81 & 4 & \\
\hline Spot 33 & 47522770 & 32 & 4 & \\
\hline Spot 34 & 47522770 & 60 & 2 & \\
\hline Spot 35 & 47522770 & 39 & 2 & \\
\hline Spot 36 & 47522770 & 99 & 2 & \\
\hline Spot 37 & 47522770 & 46 & 2 & \\
\hline Spot 38 & 47522770 & 93 & 4 & \\
\hline Spot 39 & 47522770 & 331 & 10 & \\
\hline Spot 40 & 47522770 & 106 & 4 & \\
\hline Spot 41 & 47522770 & 268 & 8 & \\
\hline Spot 42 & 50979240 & 79 & 6 & \\
\hline Spot 43 & 47522770 & 231 & 7 & \\
\hline Spot 44 & 47522770 & 239 & 4 & \\
\hline Spot 95 & 47522770 & 88 & 4 & \\
\hline Albumin & & & & $2.5 \pm 2$ \\
\hline Spot 45 & 301786252 & 298 & 9 & \\
\hline Spot 46 & 30962111 & 256 & 7 & \\
\hline Spot 96 & 3319897 & 135 & 3 & \\
\hline Spot 47 & 301786252 & 89 & 4 & \\
\hline Spot 48 & 126723746 & 884 & 31 & \\
\hline Spot 49 & 126723746 & 435 & 15 & \\
\hline Annexin 5 & & & & $2.1 \pm 1.5$ \\
\hline Spot 50 & 291401824 & 1231 & 55 & \\
\hline Spot 36 & 291401824 & 600 & 43 & \\
\hline Spot 37 & 291401824 & 801 & 47 & \\
\hline Acetylcholine receptor subunit $\alpha-7$ & & & & $0.4 \pm 0.2$ \\
\hline Spot 51 & 27806239 & 35 & 1 & \\
\hline Inter- $\alpha$-trypsin inhibitor heavy chain $\mathrm{H} 4$ precursor & & & & $1.8 \pm 0.8$ \\
\hline Spot 52 & 48374067 & 381 & 8 & \\
\hline Spot 53 & 48374067 & 420 & 10 & \\
\hline
\end{tabular}


Table 1 Continued.

\begin{tabular}{|c|c|c|c|c|}
\hline Protein and spot numbers & $\begin{array}{c}\text { NCBI accession } \\
\text { number }\end{array}$ & $\begin{array}{l}\text { MS/MS protein } \\
\text { score }\end{array}$ & $\begin{array}{c}\text { Sequence } \\
\text { covered }(\%)\end{array}$ & $\begin{array}{c}\text { Relative quantity } \\
(\text { mean } \pm \text { S.D. } \%)\end{array}$ \\
\hline Spot 54 & 48374067 & 373 & 8 & \\
\hline Spot 55 & 48374067 & 263 & 6 & \\
\hline Spot 56 & 48374067 & 376 & 9 & \\
\hline Spot 57 & 48374067 & 284 & 7 & \\
\hline Spot 58 & 48374067 & 288 & 9 & \\
\hline Spot 59 & 48374067 & 284 & 8 & \\
\hline Spot 49 & 48374067 & 67 & 3 & \\
\hline Spot 42 & 48374067 & 328 & 6 & \\
\hline Spot 60 & 48374067 & 332 & 6 & \\
\hline Spot 61 & 48374067 & 303 & 5 & \\
\hline Transferrin & & & & $0.3 \pm 0.3$ \\
\hline Spot 62 & 6175087 & 349 & 12 & \\
\hline Spot 63 & 6175087 & 97 & 4 & \\
\hline Spot 64 & 6175087 & 191 & 7 & \\
\hline Spot 65 & 6175087 & 338 & 9 & \\
\hline$\zeta$-globin-like & & & & $0.7 \pm 1$ \\
\hline Spot 66 & 291415430 & 75 & 20 & \\
\hline Ceruloplasmin precursor & & & & $0.6 \pm 0.4$ \\
\hline Spot 67 & 390517044 & 254 & 5 & \\
\hline Spot 68 & 390517044 & 381 & 6 & \\
\hline Spot 69 & 390517044 & 328 & 7 & \\
\hline T-complex protein 1 subunit gamma & & & & $0.1 \pm 0.06$ \\
\hline Spot 70 & 164448698 & 37 & 1 & \\
\hline Spot 71 & 164448698 & 37 & 1 & \\
\hline Spot 72 & 164448698 & 37 & 1 & \\
\hline Fc fragment of IgG-binding protein & & & & $1.0 \pm 0.9$ \\
\hline Spot 73 & 291414125 & 64 & 0.5 & \\
\hline Spot 74 & 297485627 & 138 & 1 & \\
\hline Spot 75 & 297485627 & 86 & 0.5 & \\
\hline Spot 76 & 297485627 & 78 & 0.5 & \\
\hline Spot 77 & 297485627 & 60 & 0.5 & \\
\hline Spot 78 & 297485627 & 73 & 0.5 & \\
\hline Spot 79 & 297485627 & 78 & 0.5 & \\
\hline Spot 80 & 297485627 & 78 & 0.5 & \\
\hline Spot 81 & 297485627 & 62 & 0.5 & \\
\hline Spot 97 & 297485627 & 77 & 0.5 & \\
\hline Carboxypeptidase E precursor & & & & $0.2 \pm 0.2$ \\
\hline Spot 82 & 148228720 & 65 & 5 & \\
\hline Spot 83 & 148228720 & 88 & 5 & \\
\hline (Predicted) hypothetical protein & & & & $0.6 \pm 0.3$ \\
\hline Spot 84 & 291391030 & 302 & 9 & \\
\hline Actin & & & & $0.4 \pm 0.2$ \\
\hline Spot 85 & 268607671 & 73 & 8 & \\
\hline Spot 86 & 45269029 & 255 & 18 & \\
\hline Spot 94 & 45269029 & 526 & 33 & \\
\hline Lipocalin-15 & & & & $0.4 \pm 0.7$ \\
\hline Spot 87 & 76631203 & 96 & 12 & \\
\hline Cathepsin L1 precursor & & & & $0.2 \pm 0.07$ \\
\hline Spot 88 & 47522698 & 160 & 11 & \\
\hline Hexosaminidase B & & & & $0.8 \pm 0.3$ \\
\hline Spot 89 & 262072808 & 111 & 6 & \\
\hline Spot 90 & 262072808 & 141 & 7 & \\
\hline Spot 91 & 262072808 & 155 & 8 & \\
\hline Spot 92 & 262072808 & 74 & 4 & \\
\hline Laminin $\alpha$ 5-like & & & & $0.1 \pm 0.08$ \\
\hline Spot 93 & 296484172 & 47 & 1 & \\
\hline Tetraspanin CD63 & & & & $0.04 \pm 0.01$ \\
\hline Spot 98 & 126723685 & 88 & 10 & \\
\hline
\end{tabular}

asymmetry and kurtosis, using the UNIVARIATE procedure with NORMAL and PLOT options of the Statistical Analysis System (SAS 2003). Variables without a normal distribution (Shapiro-Wilk's, $P<0.05)$ were $\log (\log (x+1))$ or angularly (arcsin $\sqrt{ } x / 100)$ transformed. Associations between seminal plasma parameters and the intensities of the spots detected in the 2D maps of the animals were estimated by Pearson's (when two parametric variables were associated) or Spearman's (when at least one non-parametric variable was used in the association) method (using the CORR procedures, SAS (2003)). Only spots expressed in all gels were included in the analysis of correlation. 


\section{Results}

All semen collection attempts conducted in the nine animals resulted in ejaculation. All ejaculates were white, watery, and contained sperm. Total volume of ejaculates was $2 \pm 1.1 \mathrm{ml}$, with a sperm concentration of $207 \pm 160.7 \times 10^{6}$ spermatozoa $/ \mathrm{ml}$. Sperm motility was $83 \pm 20.9 \%$, with vigor of $4.2 \pm 1.1$. Percentages of viable sperm (sperm membrane integrity), morphologically normal sperm, and sperm presenting functionally intact membrane were $72.6 \pm 10.4,80 \pm 21$, and $80.4 \pm 14.1 \%$ respectively.

The average protein concentration in seminal plasma samples from collared peccaries was $34.1 \pm 14 \mathrm{mg} / \mathrm{ml}$. Based on the analysis of a PDQuest Software match set with nine gels constructed within the 4-7 $\mathrm{pH}$ range, we detected 179 protein spots per gel (Fig. 1A and B). The master gel consistently showed 82 spots $(46 \%$ of all spots) present in every protein map and intensities of these spots corresponded to $92.3 \%$ of the total intensity of all spots depicted in the seminal plasma maps. Ninetyeight spots were identified by MS/MS, corresponding to 23 different proteins (Fig. 1, Table 1, and Supplementary Table 1, see section on supplementary data given at the end of this article). The combined intensity of those spots accounted for $56.2 \%$ of the intensities of the all spots and $60.9 \%$ of the intensities of spots presented in every protein map.

Spots identified as clusterin represented $19.7 \pm 8.3 \%$ of the integrated optical densities of all spots detected in the seminal plasma maps. There was a negative association $(r=-0.87 ; P<0.05)$ between the intensity of a clusterin spot (spot no. 27; Fig. 1) and the percentage of sperm with functional membrane. In fact, that was the unique significant association found between a seminal plasma protein and a semen characteristic in the peccary.

Spermadhesins, identified as spermadhesin porcine seminal plasma protein 1 (PSP-1) and bodhesin 2 (Bdh-2), comprised $5.4 \pm 1.9$ and $8.8 \pm 3.9 \%$ of the total intensity of all valid spots in the gels respectively. Other major proteins found in the peccary seminal plasma include epididymal secretory glutathione peroxidase (GPX, $6.1 \pm 1.3 \%)$, albumin $(2.5 \pm 2 \%)$, and annexin 5 (ANX5, $2.1 \pm 1.5 \%$ ). Many proteins appeared in a polymorphic pattern in the seminal plasma map, as trains of isoforms, such as clusterin (27 spots), epididymal secretory GPX (ten spots), inter- $\alpha$-trypsin inhibitor (12 spots), IgG-binding protein (IgGBP, ten spots), PSP-1 (three spots), albumin (six spots), transferrin (four spots), and hexosaminidase B (four spots), among others. Other proteins identified in the seminal plasma of collared peccaries include $\zeta$-globin, ceruloplasmin, carboxypeptidase $\mathrm{E}$, and $\mathrm{T}$ complex-containing chaperonins (Fig. 1, Table 1, and Supplementary Table 1).

Biological processes of peccary seminal plasma proteins are linked to cellular process $(22 \%)$, regulation

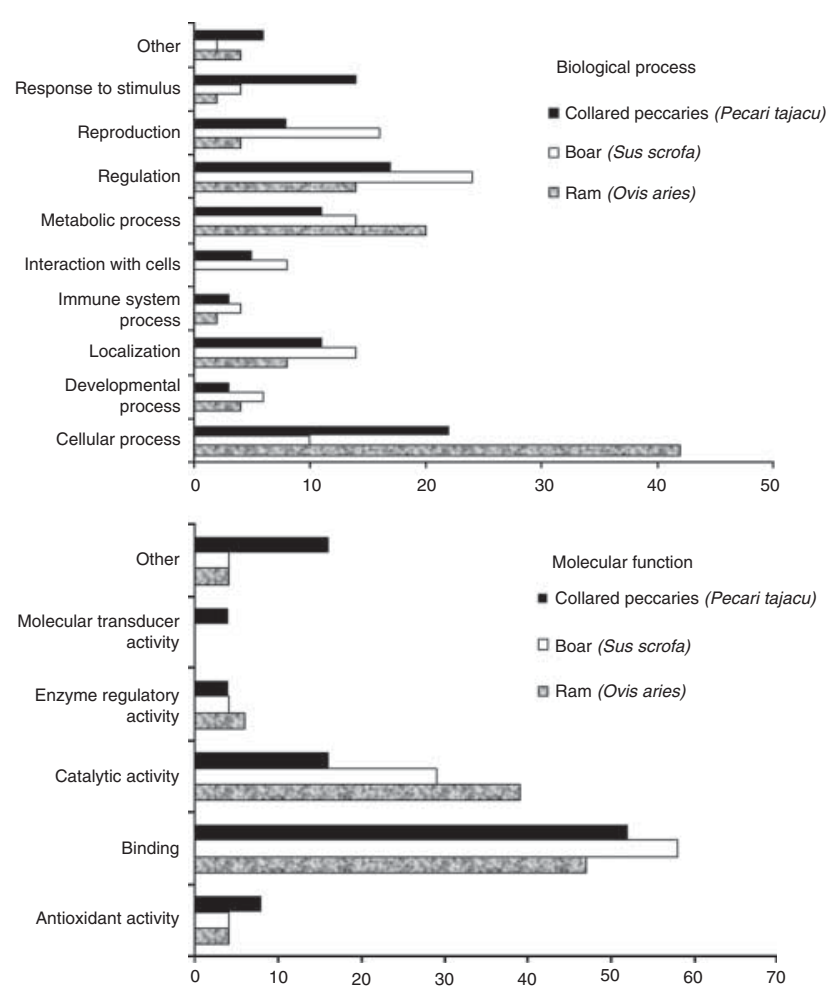

Figure 2 Gene ontology annotations of the Pecari tajacu seminal plasma proteome based on their biological process and molecular function. Protein data were analysed using the Software for Researching Annotations of Proteins. Gene ontology terms were obtained from UniProtKB and EBI GOA databases. Gene ontology associated with peccary seminal plasma proteins was also compared with that of rams (Souza et al. 2012) and domestic boar (S. scrofa; V R Cadavid, J M Martins \& A A Moura 2013, unpublished results). Comparisons were only made using gene ontology analysis previously conducted with the same software used in the present study.

$(17 \%)$, response to stimulus $(14 \%)$, localization, and reproduction $(11 \%)$. As a reference, biological processes of seminal proteins were mainly associated with cellular process, response to stimulus, regulation, and reproduction as found in the ram and domestic swine (Fig. 2). As for molecular functions, peccary seminal proteins mostly participate in binding (52\%), followed by catalytic (16\%) and antioxidant activities (8\%), and enzyme regulatory and molecular transducer activity (4\%). Gene ontology annotations defined as antioxidant, catalytic, and molecular transducer activity appear more distinct when compared to those of ram and swine proteins (Fig. 2).

Network analysis (Fig. 3) showed that clusterin interacts with a wide range of protein groups, such as $\alpha$-2-plasmin inhibitor (SERPINF2), tissue inhibitor of metalloproteinase 1 (TIMP-1), fibronectin precursor (FN1), plasminogen precursor (PLG), $\alpha$-2-macroglobulin (A2M), and secreted protein acidic and rich in cysteine (SPARC), among others. 

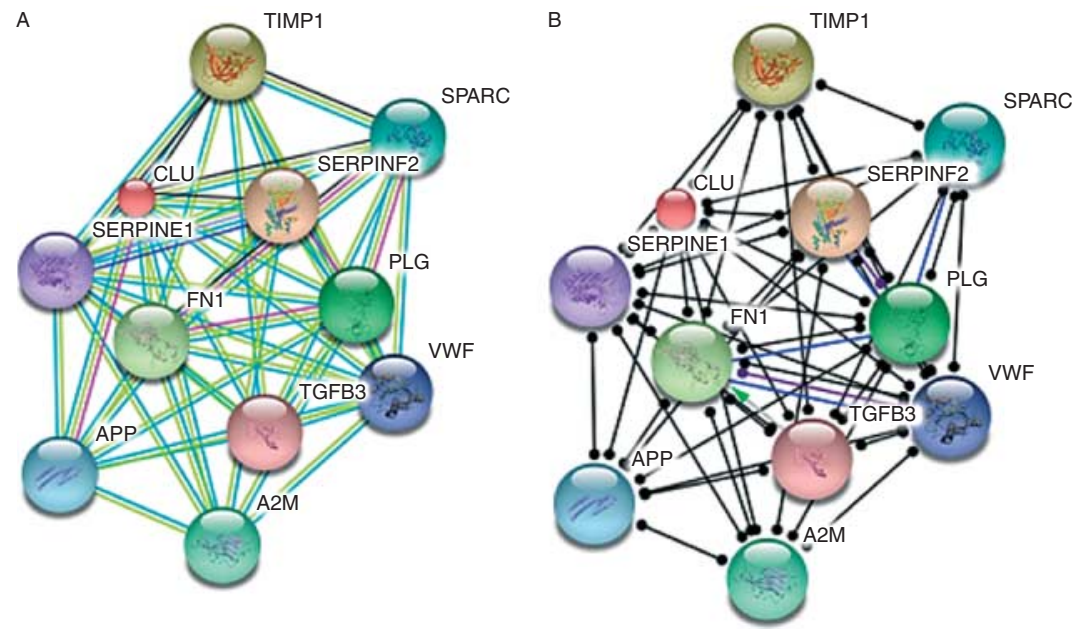

Figure 3 Schematic view of known and predicted protein interactions for clusterin, according to the STRING database (v. 9.05). Given the absence of Pecari tajacu clusterin sequence, we selected the information from Bos taurus. Only interactions with the highest confidence score (0.900) are shown. Interactions include physical and functional associations, showing the evidence (A) and action (B) views. CLU, clusterin; SERPINF2, $\alpha$-2-plasmin inhibitor; TIMP-1, tissue inhibitor of metalloproteinase 1; FN1, fibronectin precursor; PLG, plasminogen precursor; A2M, $\alpha$-2-macroglobulin; SPARC, secreted protein acidic and rich in cysteine; APP, amyloid $\beta 4$ protein; VWF, Von Willebrand factor; SERPINE1, plasminogen activator inhibitor 1 ; TGFB3, transforming growth factor $\beta 3$.

\section{Discussion}

A combination of 2D electrophoresis, computerized analysis of gel images, and MS/MS enabled us to compile a comprehensive profile of the major seminal plasma proteins of $P$. tajacu. To our knowledge, this is the first survey of the seminal plasma proteome of adult and reproductively sound peccaries. Peccary seminal proteins are diverse and potentially affect reproduction by several mechanisms. Below, we discuss the main attributes of such proteins according to their functional groups.

\section{Proteins associated with protection of sperm integrity and function}

In the present work, specific proteins were associated with sperm protection, acting as chaperones and antioxidants. As chaperones, the peccary seminal plasma expresses clusterin and T-complex protein 1, subunit gamma, while proteins with antioxidant properties include selenium-independent GPX5, ceruloplasmin, albumin, and transferrin. In several domestic mammals, the epididymis is a major source of scavengers for reactive oxygen species in the reproductive tract and contains appreciable amounts of superoxide dismutase, catalase, and GPX (Dacheux et al. 2006, Moura et al. 2010). As shown for other species, it is likely that GPX5 protects peccary sperm cells against hydrogen peroxide and lipoperoxides, maintaining membrane functionality and preventing loss of motility (Alvarez \& Storey 1989) and premature acrosome reaction (Vernet et al. 1999).

As it is well known, albumin is secreted in nearly all body fluids and, in semen, it protects sperm by binding to free fatty acid hydroperoxides, preventing oxidative damages (Storey 1997). Accessory sex glands and epididymides secrete albumin in several domestic mammals (Dacheux et al. 2006, Moura et al. 2007, 2010, Souza et al. 2012). This protein interacts with the sperm membrane during epididymal transit and spermbound albumin participates in the fertilization process as well (Gonçalves et al. 2008). Transferrin, in turn, is an iron-binding protein found in the peccary seminal plasma and probably acts by chelating excess of free ionic iron, protecting sperm against lipid peroxidation (Wakabayashi et al. 1999), and preventing bacterial growth (Farnaud \& Evans 2003). However, transferrin only reacts with ferric iron and ferrous iron must then be converted to the ferric state in order to bind transferrin. This conversion is catalyzed by ceruloplasmin, a coppercontaining enzyme with ferroxidase activity, identified in the peccary seminal plasma (Hellman \& Gitlin 2002). In addition, ceruloplasmin has antioxidant properties, acting as an effective scavenger for superoxide anions (Goldstein et al. 1979). Seminal plasma transferrin correlates with sperm counts and fertility in men (Foresta et al. 1986) and lactotransferrin is associated with sperm motility in Asian elephants (Kiso et al. 2013). TCP1containing chaperonins (CCTs) are present on the sperm surface of mice and boars (Belleannée et al. 2011) and mediate sperm-oocyte interaction (Dun et al. 2011). Interestingly, the presence of CCTs 5 and 8 in bull sperm membrane was negatively correlated with fertility. A possible explanation for such relationship would be related to the failure in removal of CCTs in the final stages of spermatogenesis (D'amours et al. 2010). The precise role played by CCT3 chaperonin identified in the peccary seminal plasma remains unclear, but one possibility is that CCT3 interacts with other chaperones, such as clusterin, preventing protein degradation during epididymal maturation.

Clusterin was the most polymorphic (27 spots) and abundant protein group in the peccary seminal plasma gels. Even when compared with clusterin expression in the reproductive fluids of other species, we have studied using the same 2D SDS-PAGE approach, such as the bovine (Moura et al. 2007, 2010), ovine (Souza et al. 2012), and domestic swine (S. scrofa; V R Cadavid, 
J M Martins \& A A Moura 2013, unpublished results), clusterin abundance and isoform diversity in the peccary seminal plasma is much greater and, thus, unique. However, the precise functional meaning of such event is unclear. Clusterin is multifunctional, acting as a chaperone (Humphreys et al. 1999), protecting reproductive tract cells against apoptosis (Bailey et al. 2002) or complement attack (Meri \& Jarva 2001), and assisting with removal of damaged sperm in the epididymis of men (Zalata et al. 2012). The chaperone activity of clusterin is consistent with its propensity to interact with different proteins in vivo (Carver et al. 2003) and in acoordance with the network analysis we presently show. Based on such analysis, clusterin can interact with regulators of cell growth (such as SPARC), as well as with proteases and protease inhibitors, such as PLG, A2M, TIMP-1, $\alpha$-2-antiplasmin precursor, and plasminogen activator inhibitor 1 . Clusterin also has potential links to fibronectins, which participate in cell adhesion, healing of wounds, and maintenance of cell structure, GTP protein-coupled receptors (amyloid $\beta$ A4 protein), and modulators of cell growth, such as TGFB3. Thus, pronounced expression and isoform diversity of clusterin in the peccary seminal plasma may be related to its broad functional attributes. Additionally, we report that the intensity of a clusterin spot (no. 27, Fig. 1) was negatively associated with the percentage of sperm with intact membrane. In bulls and rams, sperm with morphologic defects, in contrast with normal cells, exhibit extensive clusterin binding (Ibrahim et al. $2001 a, b)$. This association probably occurs as a result of clusterin's ability to bind damaged portions of sperm membrane hydrophobic regions (Bailey \& Griswold 1999). Although significant, the correlation presently shown between clusterin and a sperm parameter was based on a group of only eight animals and it needs, therefore, to be confirmed in experiments with larger samples.

$\mathrm{H} 4$ heavy chain (ITIH4) is a member of the inter- $\alpha$ trypsin inhibitor family acting rather as an acute-phase protein (Piñeiro et al. 2004). Some of these proteins, such as $\alpha$-1-antitrypsin, have been described a component of the reproductive tract fluids of bulls (Moura et al. 2010), where they modulate host-defensive actions to inflammatory reactions and infections. Similar to clusterin, ITIH4 inhibits complement activation and complementassociated phagocytosis and damage (Garantziotis et al. 2008). Thus, it is possible that these proteins work together to protect sperm against inflammatory reactions.

In humans and animals, antisperm antibodies can react with sperm surface proteins and impairs fertilization. To mitigate such effects, at least in humans, seminal plasma contains IgGBP, which bind IgGs via the Fc fragment and prevent them from reaching the sperm (Chiu \& Chamley 2003). To the best of our knowledge, this is the first report of IgGBP in the seminal plasma of either domestic or wild animals. Molecular weights of
IgGBP identified in the present work are similar to those of human IgGBPs (Witkin et al. 1983) and likely play a similar role.

\section{Lipophilic proteins}

Lipocalin-15 protein is the boar homolog of the lipocalin-type prostaglandin-D-synthase (PGDS). These proteins belong to the lipocalin family, which consists of small secretory proteins sharing a common feature of binding and transporting lipophilic molecules (Pervaiz \& Brew 1987). In bulls, PGDS binds to the acrosomal cap of cauda epididymal sperm and PGDS spot intensity in seminal plasma 2D maps is positively associated with bull fertility (Gerena et al. 2000). Moreover, treatment of sperm or oocytes with antibodies against bovine PGDS decreases fertilization rates and early embryo development (Gonçalves et al. 2008). It is therefore possible that PGDS, a typical epididymal protein, influences events related to the fertilization process. Epididymal secretory protein - E1 (HE1), another lipophilic component detected in the peccary seminal fluid, has been found in the bull (Moura et al. 2010), boar (Okamura et al. 1999), and human (Dacheux et al. 2006) cauda epididymal fluid, and in the seminal plasma of rams (Souza et al. 2012). HE1 is also involved in sperm membrane modification during epididymal maturation (Okamura et al. 1999).

Annexins are calcium-dependent, phospholipid-binding components and ANX5 is a component of human seminal plasma, protecting both DNA and sperm membrane integrity against oxidative damage (Lu et al. 2011). ANX5 is also the major protein of rabbit seminal plasma (Arruda-Alencar et al. 2012), where it is mainly expressed as $66-70 \mathrm{kDa}$ isoforms, making nearly $38 \%$ of all spot intensities in 2D gels. In the peccary, ANX5 represents only $2 \%$ of all spot intensities, but the three ANX5 spots have $\mathrm{kDa}$ and $\mathrm{pH}$ values similar to those found in the rabbit seminal plasma gels. ANX5 function in the peccary semen is still unknown, but it is possible that it has a protective role, as shown for humans (Lu et al. 2011).

\section{Proteins mediating formation of the oviduct reservoir and sperm-oocyte interaction}

The PSP-1 and Bdh-2 are members of the spermadhesin family detected in the collared peccaries seminal plasma. Spermadhesins are secreted by both the porcine epididymis and accessory sex glands (EkhlasiHundrieser et al. 2002) and, in the seminal fluid, PSP-1 forms a heterodimer with PSP-2 (Calvete et al. 1995), which binds to the sperm acrosome. PSP-1/PSP-2 complex is the most abundant protein group of the boar seminal plasma, corresponding to at least 50\% of all proteins (Calvete et al. 1995, V R Cadavid, 
J M Martins \& A A Moura 2013, unpublished results). This contrasts with the analysis of peccary seminal fluid, where clusterin is the predominant protein and spermadhesins are in much lower concentration. In the swine, ejaculates with higher percentage of PSP-1/PSP2-positive cells have higher proportion of motile and metabolically active sperm (Caballero et al. 2006) and these properties are mostly due to PSP-1/PSP-2 decapacitating ability (García et al. 2006). PSP-1/PSP-2 also stimulates leukocyte migration to the uterus shortly after ejaculation (Assreuy et al. 2003), thus providing a uterine environment free of microorganisms. In the domestic swine, purified PSP-1/PSP-2 have beneficial effects on sperm viability when added to semen extenders (Centurion et al. 2003). Particularly in the boar, spermadhesins are involved in the formation of the oviduct reservoir and sperm-egg binding, interacting with oocyte receptors through its CUB domain (TopferPetersen et al. 2008). Therefore, it is possible that spermadhesins of the peccary seminal plasma bind to sperm and affect such events before and during fertilization as well.

Acetylcholine receptors (AChR) are present in the midpiece of mouse sperm, where they regulate motility probably due to its ability to increase calcium uptake (Bray et al. 2005). Additionally, AChR functions in zona pellucida-induced acrosome reaction, involving the increase in intra-sperm calcium content and phospholipase C activation (Jaldety et al. 2012). Such roles in sperm function are critical, since $\alpha 7$-null mouse sperm have impaired motility (Bray et al. 2005). Given that CHRNA7 was found in the peccary seminal plasma as a single spot and representing only $0.2 \%$ of all spot intensities, it is possible that this protein probably derives from a sperm cell and may not represent a component truly secreted in the seminal plasma.

Glycosidases, such as galactosidase, fucosidase, and mannosidase, among others, are common components of the seminal plasma of several species, such as rams (Souza et al. 2012), humans (Corrales et al. 2002), and bulls (Kelly et al. 2006). Glycosidases mostly come from the epididymis, where they modify sperm surface glycoproteins during maturation (Dacheux et al. 2006). Additionally, some glycosidases bind to sperm membrane glycosidic residues and act as sites to either recognize the oviductal epithelium (Talevi \& Gualtieri 2010) or to participate in human sperm-egg interaction through zona-pellucida glycoproteins (Miranda et al. 2000). Hexosaminidases bind to human sperm membrane during epididymal transit (Perez Martinez et al. 2008) and participate in sperm-zona pellucida interaction (Miranda et al. 2000). In the peccary seminal fluid, hexosaminidase is expressed as four isoforms with $102 \mathrm{kDa}$, very similar to the boar seminal hexosaminidase (Daron \& Aull 1985). It is likely therefore that this protein participates in sperm-egg recognition, as shown for other species.
Tetraspanins have transmembrane domains and are involved in protein trafficking. Some tetraspanins, such as CD9 and CD81, play a role in sperm-egg fusion, probably through links with integrins (Ziyyat et al. 2006). Such proteins are present in human prostasomes and epididymosomes, structures that mediate the transfer of components to sperm, either during epididymal maturation or after ejaculation. This study is the first to describe tetraspanin CD63 in the seminal plasma of any species but its precise function in reproductive events is still unclear.

$\alpha$-S1-casein was found in the peccary seminal plasma. As well established, caseins are major proteins of milk, but $\alpha$-S1-casein has been detected in human prostate secretions (Xu et al. 2012) and in the membrane of ejaculated sperm, participating in bovine (Pate et al. 2008) and swine (Mori et al. 1996) sperm-egg fusion. Given that S1-casein stabilizes calcium ions in solution and enhances calcium incorporation in numerous cell types, such protein likely plays a role in the acrosome reaction (Mori et al. 1996).

\section{Proteases}

Carboxypeptidase E and cathepsin L1 are proteases identified in the peccary seminal plasma. The former is synthesized in the boar epididymis (Guyonnet et al. 2009) and possibly modifies sperm membrane proteins during epididymal maturation (Métayer et al. 2002). Cathepsins, in turn, are cysteine proteases and cathepsin L1 precursor (procathepsin L) identified in the present work likely comes from the epididymis, as also found in the rat (Tomomasa et al. 1994), bull (Moura et al. 2010), and boar (Okamura et al. 1995). Pro-enzymes are activated to mature cathepsins in epididymal fluid (Tomomasa et al. 1994) and believed to affect sperm maturation and its fertilizing capacity. Indeed, cauda epididymal fluid cathepsin D is positively associated with fertility of dairy bulls (Moura et al. 2006).

\section{Other proteins from the seminal plasma}

Actin is a putative intracellular protein, associated with the cytoskeleton, and act as sperm undergo capacitation and acrosome reaction (Brener et al. 2002). Nevertheless, this protein is consistently found as a component of ram seminal plasma (Souza et al. 2012) and cauda epididymal fluid of bulls (Moura et al. 2010). Actin has no confirmed function in the reproductive fluids and its presence in such secretions is more likely the result of leakage from damaged or dead sperm. A $\zeta$-globin-like protein has been recently reported as one of the major seminal plasma proteins in rabbits (Arruda-Alencar et al. 2012), but there are no reports on such protein in the seminal plasma of other species. 
In conclusion, this study describes the major proteome of the seminal plasma of $P$. tajacu. Gene ontology analysis confirms similarities and differences with the ram, a ruminant, and the domestic swine. Also in comparison with the $S$. scrofa, the closely related species, the peccary seminal fluid shows a distinct high expression of clusterin isoforms and less amount of spermadhesins. As for other species, seminal plasma proteins of the peccary are potentially involved in several reproductive processes, such as sperm protection, modification of sperm membrane, formation of the oviduct reservoir and sperm-egg binding. Knowledge of wild species reproductive biology is crucial for a complete understanding of their survival strategies and adaptation in a changing environment. Also, it sets the foundation for assisted reproduction techniques such as gamete cryopreservation, artificial insemination, and IVF.

\section{Supplementary data}

This is linked to the online version of the paper at http://dx.doi. org/10.1530/REP-13-0220.

\section{Declaration of interest}

The authors declare that there is no conflict of interest that could be perceived as prejudicing the impartiality of the research reported.

\section{Funding}

The Brazilian Research Council (process 558317/2009-0) supported this work.

\section{References}

Alvarez JG \& Storey BT 1989 Role of glutathione peroxidase in protecting mammalian spermatozoa from loss of motility caused by spontaneous lipid peroxidation. Gamete Research 23 77-90. (doi:10.1002/mrd. 1120230108)

Arruda-Alencar JM, Viana-Neto AM, Souza CE, Martins JAM, Moreno FB, Moreira ACO, Guerreiro MEF \& Moura AA 2012 Major proteins of the seminal plasma of New Zealand white rabbits and association with semen criteria. 10th World Rabbit Congress World Rabbit Science Association, Sharm El-Sheikh, Egypt. 395-399.

Assreuy AM, Alencar NM, Cavada BS, Rocha-Filho DR, Feitosa RF, Cunha FQ, Calvete JJ \& Ribeiro RA 2003 Porcine spermadhesin PSPI/PSP-II stimulates macrophages to release a neutrophil chemotactic substance: modulation by mast cells. Biology of Reproduction $\mathbf{6 8}$ 1836-1841. (doi:10.1095/biolreprod.102.013425)

Bailey RW, Aronow B, Harmony JaK \& Griswold MD 2002 Heat shock-initiated apoptosis is accelerated and removal of damaged cells is delayed in the testis of clusterin/apol knockout mice. Biol Reprod $\mathbf{6 6}$ 1042-1053. (doi:10.1095/biolreprod66.4.1042)

Bailey R \& Griswold MD 1999 Clusterin in the male reproductive system: localization and possible function. Molecular and Cellular Endocrinology 151 17-23. (doi:10.1016/S0303-7207(99)00016-7)

Belleannée C, Belghazi M, Labas V, Teixeira-Gomes AP, Gatti JL, Dacheux JL \& Dacheux F 2011 Purification and identification of sperm surface proteins and changes during epididymal maturation. Proteomics 11 1952-1964. (doi:10.1002/pmic.201000662)
Bianchi T, Collares VF, Campos PV, Cavalanti C, Kaefer EK, Correa AO, Dellagostin T, Lucia JC \& Deschampps MN 2008 Fator do plasma seminal asssociado à integridade de membrana de espermatozóides suínos pós descongelamento. Arquivo Brasileiro de Medicina Veterinária e Zootecnia 60 384-388. (doi:10.1590/S0102-09352008000200017)

Bradford MM 1976 A rapid and sensitive method for the quantitation of microgram quantities of protein utilizing the principle of protein-dye binding. Analytical Biochemistry 72 248-254. (doi:10.1016/00032697(76)90527-3)

Bray C, Son JH, Kumar P \& Meizel S 2005 Mice deficient in chrna7, a subunit of the nicotinic acetylcholine receptor, produce sperm with impaired motility. Biology of Reproduction 73 807-814. (doi:10.1095/ biolreprod.105.042184)

Brener E, Rubinstein S, Cohen G, Shternall K, Rivlin J \& Breitbart H 2002 Remodeling of the actin cytoskeleton during mammalian sperm capacitation and acrosome reaction. Biology of Reproduction 68 837-845. (doi:10.1095/biolreprod.102.009233)

Caballero I, Vázquez JM, García EM, Roca J, Martínez EA, Calvete JJ, Sanz L, Ekwall H \& Rodríguez-Martínez H 2006 Immunolocalization and possible functional role of PSP-I/PSP-II heterodimer in highly extended boar spermatozoa. Journal of Andrology 27 766-773. (doi:10.2164/jandrol.106.000539)

Calvete JJ, Mann K, Schafer W, Raida M, Sanz L \& Topfer-Petersen E 1995 Boar spermadhesin PSP-II: location of posttranslational modifications, heterodimer formation with PSP-I glycoforms and effect of dimerization on the ligand-binding capabilities of the subunits. FEBS Letters 365 179-182. (doi:10.1016/0014-5793(95)00452-F)

Carver JA, Rekas A, Thorn DC \& Wilson MR 2003 Small heat-shock proteins and clusterin: intra- and extracellular molecular chaperones with a common mechanism of action and function? IUBMB Life $\mathbf{5 5}$ 661-668. (doi:10.1080/15216540310001640498)

Castelo TS, Bezerra FS, Souza AL, Moreira MA, Paula VV, Oliveira MF \& Silva AR 2010 Influence of the thawing rate on the cryopreservation of semen from collared peccaries (Tayassu tajacu) using Tris-based extenders. Theriogenology 74 1060-1065. (doi:10.1016/j.theriogenology.2010.05.002)

Centurion F, Vazquez JM, Calvete JJ, Roca J, Sanz L, Parrilla I, García EM \& Martínez EA 2003 Influence of porcine spermadhesins on the susceptibility of boar spermatozoa to high dilution. Biology of Reproduction 69 640-646. (doi:10.1095/biolreprod.103.016527)

Chiu WW \& Chamley LW 2003 Human seminal plasma antibody-binding proteins. American Journal of Reproductive Immunology 50 196-201. (doi:10.1034/j.1600-0897.2003.00067.x)

Corrales JJ, Burgo RM, Galindo P, Munoz-Barroso I, Miralles JM \& Villar E 2002 Abnormal expression of acid glycosidases in seminal plasma and spermatozoa from infertile men with varicocele. Reproduction 123 411-417. (doi:10.1530/rep.0.1230411)

Costa DS, Henry M \& Paula TAR 2004 Spermatogenesis of collared peccary (Tayassu tajacu). Arquivo Brasileiro de Medicina Veterinária e Zootecnia 56 46-55. (doi:10.1590/S0102-09352004000100008)

Dacheux JL, Belghazi M, Lanson Y \& Dacheux F 2006 Human epididymal secretome and proteome. Molecular and Cellular Endocrinology 250 36-42. (doi:10.1016/j.mce.2005.12.022)

D'amours O, Frenette G, Fortier MA, Leclerc P \& Sullivan R 2010 Proteomic comparison of detergent-extracted sperm proteins from bulls with different fertility indexes. Reproduction 139 545-556. (doi:10.1530/REP-09-0375)

Daron HH \& Aull JL 1985 Purification and properties of $\beta$ - $N$-acetylD-hexosaminidase from boar seminal plasma. International Journal of Biochemistry 17 581-588. (doi:10.1016/0020-711X(85)90289-7)

Dun MD, Smith ND, Baker MA, Lin M, Aitken RJ \& Nixon B 2011 The chaperonin containing TCP1 complex (CCT/TRiC) is involved in mediating sperm-oocyte interaction. Journal of Biological Chemistry 286 36875-36887. (doi:10.1074/jbc.M110.188888)

Ekhlasi-Hundrieser M, Sinowatz F, De Wilke IG, Waberski D \& TopferPetersen E 2002 Expression of spermadhesin genes in porcine male and female reproductive tracts. Molecular Reproduction and Development 61 32-41. (doi:10.1002/mrd.1128)

Farnaud S \& Evans RW 2003 Lactoferrin - a multifunctional protein with antimicrobial properties. Molecular Immunology 40 395-405. (doi:10.1016/S0161-5890(03)00152-4) 
Flowers WL \& Turner ZA 2001 Relationships between seminal plasma protein profiles and estimates of fertility for boars. In: VIth International Conference on Pig Reproduction, pp 65. Greenville, NC: University of Missouri.

Foresta C, Manoni F, Businaro V, Donadel C, Indino M \& Scandellari C 1986 Possible significance of transferrin levels in seminal plasma of fertile and infertile men. Journal of Andrology 7 77-82. (doi:10.1002/ j.1939-4640.1986.tb00883.x)

Garantziotis S, Zudaire E, Trempus CS, Hollingsworth JW, Jiang D, Lancaster LH, Richardson E, Zhuo L, Cuttitta F, Brown KK et al. 2008 Serum inter- $\alpha$-trypsin inhibitor and matrix hyaluronan promote angiogenesis in fibrotic lung injury. American Journal of Respiratory and Critical Care Medicine 178 939-947. (doi:10.1164/rccm.2008033860C)

Garcia L, Acevedo M \& Rossini M 2000 Aspectos histologicos del tracto genital masculino del baquiro de colar. III. Caracteristicas de las glandulas anexas. Veterinaria Tropical 25 277-284.

García EM, Vazquez JM, Calvete IJ, Sanz L, Caballero I, Parrilla I, Gil MA, Roca J \& Martínez EA 2006 Dissecting the protective effect of the seminal plasma spermadhesin PSP-I/PSP-II on boar sperm functionality. Journal of Andrology 27 434-443. (doi:10.2164/jandrol.05170)

Gerena RL, Irikura D, Urade Y, Eguchi N \& Killian GJ 2000 Immunocytochemical localization of lipocalin-type prostaglandin D synthase in the bull testis and epididymis and on ejaculated sperm. Biology of Reproduction 6 547-556. (doi:10.1095/biolreprod62.3.547)

Goldstein IM, Kaplan HB, Edelson HS \& Weissmann G 1979 Ceruloplasmin: a scavenger of superoxide anion radicals. Journal of Biological Chemistry 254 4040-4045.

Gonçalves RF, Staros AL \& Killian GJ 2008 Oviductal fluid proteins associated with the bovine zona pellucida and the effect on in vitro sperm-egg binding, fertilization and embryo development. Reproduction in Domestic Animals 43 720-729. (doi:10.1111/j.1439-0531.2007. 00978.x)

Guyonnet B, Marot G, Dacheux JL, Mercat MJ, Schwob S, Jaffrézic F \& Gatti JL 2009 The adult boar testicular and epididymal transcriptomes. BMC Genomics 10 369. (doi:10.1186/1471-2164-10-369)

Hellgren EC, Lochmiller RL, Amoss MSS Jr, Seager WJ, Magyar SJ, Coscarelli KP \& Grant WE 1989 Seasonal variation in serum testosterone, testicular measurements and semen characteristics in the collared peccary (Tayassu tajacu). Journal of Reproduction and Fertility 85 677-686. (doi:10.1530/jrf.0.0850677)

Hellman NE \& Gitlin JD 2002 Ceruloplasmin metabolism and function. Annual Review of Nutrition 22 439-458. (doi:10.1146/annurev.nutr.22. 012502.114457)

Huang SY, Kuo YH, Lee YP, Tsou HL, Lin EC, Ju CC \& Lee WC 2000 Association of heat shock protein 70 with semen quality in boars. Animal Reproduction Science 63 231-240. (doi:10.1016/S03784320(00)00175-5)

Humphreys DT, Carver JA, Easterbrook-Smith SB \& Wilson MR 1999 Clusterin has chaperone-like activity similar to that of small heat shock proteins. Journal of Biological Chemistry 274 6875-6881. (doi:10.1074/ jbc.274.11.6875)

Ibrahim NM, Foster DN \& Crabo BG 2001a Localization of clusterin on freeze-preserved bull spermatozoa before and after glass wool-sephadex filtration. Journal of Andrology 22 891-902. (doi:10.1002/j.1939-4640. 2001.tb02594.x)

Ibrahim NM, Romano JE, Troedsson MH \& Crabo BG 2001 b Effect of scrotal insulation on clusterin-positive cells in ram semen and their relationship to semen quality. Journal of Andrology 22 863-877. (doi:10.1002/ j.1939-4640.2001.tb02592.x)

Jaldety Y, Glick Y, Orr-Urtreger A, Ickowicz D, Gerber D \& Breitbart H 2012 Sperm epidermal growth factor receptor (EGFR) mediates $\alpha 7$ acetylcholine receptor (AChR) activation to promote fertilization. Journal of Biological Chemistry 287 22328-22340. (doi:10.1074/jbc. M111.292292)

Kelly VC, Kuy S, Palmer DJ, Xu Z, Davis SR \& Cooper GJ 2006 Characterization of bovine seminal plasma by proteomics. Proteomics 6 5826-5833. (doi:10.1002/pmic.200500830)

Kiso WK, Selvaraj V, Nagashima J, Asano A, Brown JL, Schmitt DL, Leszyk J, Travis AJ \& Pukazhenthi BS 2013 Lactotransferrin in Asian elephant (Elephas maximus) seminal plasma correlates with semen quality. PLOS ONE 8 e71033. (doi:10.1371/journal.pone.0071033)
Lu R, Guo C, Tao XQ, Liu HY, Shi SS, Lin CY \& Yao B 2011 Protective effect of annexin 5 on human sperm membrane and DNA integrity. Zhonghua Nan Ke Xue 17 17-20.

Mayor P, Galvez H, Guimarães DA, López-Gatius F \& López-Béjar M 2007 Serum estradiol-17 $\beta$, vaginal cytology and vulvar appearance as predictors of estrus cyclicity in the female collared peccary (Tayassu tajacu) from the eastern Amazon region. Animal Reproduction Science 97 165-174. (doi:10.1016/j.anireprosci.2005.12.017)

Meri S \& Jarva H 2001 Complement regulatory proteins. Nature Encyclopedia of Life Sciences 1 1-8.

Métayer S, Dacheux F, Dacheux JL \& Gatti JL 2002 Comparison, characterization, and identification of proteases and protease inhibitors in epididymal fluids of domestic mammals. Matrix metalloproteinases are major fluid gelatinases. Biology of Reproduction 66 1219-1229. (doi:10.1095/biolreprod66.5.1219)

Miranda PV, González-Echeverría F, Blaquier JA, Mahuran DJ \& Tezón JG 2000 Evidence for the participation of $\beta$-hexosaminidase in human sperm-zona pellucida interaction in vitro. Molecular Human Reproduction 6 699-706. (doi:10.1093/molehr/6.8.699)

Mori T, Hirayama M, Suzuki K, Shimizu H \& Nagai T 1996 Effect of casein phospho peptides and $\mathrm{Ca}^{2+}$ on penetration of boar spermatozoa into pig oocytes matured in vitro. Biology of Reproduction 55 364-369. (doi:10.1095/biolreprod55.2.364)

Moura AA, Chapman DA, Koc H \& Killian GJ 2006 Proteins of the cauda epididymal fluid associated with fertility of mature dairy bulls. Journal of Andrology 27 534-541. (doi:10.2164/jandrol.05201)

Moura AA, Chapman DA, Koc H \& Killian GJ 2007 A comprehensive proteomic analysis of the accessory sex gland fluid from mature Holstein bulls. Animal Reproduction Science 98 169-188. (doi:10.1016/j. anireprosci.2006.03.012)

Moura AA, Souza CE, Stanley BA, Chapman DA \& Killian G) 2010 Proteomics of cauda epididymal fluid from mature Holstein bulls. Journal of Proteomics 73 2006-2020. (doi:10.1016/j.jprot.2010.06.005)

Okamura N, Tamba M, Uchiyama Y, Sugita Y, Dacheux F, Syntin P \& Dacheux JL 1995 Direct evidence for the elevated synthesis and secretion of procathepsin $\mathrm{L}$ in the distal caput epididymis of boar. Biochimica et Biophysica Acta 1245 221-226. (doi:10.1016/03044165(95)00109-O)

Okamura N, Kiuchi S, Tamba M, Kashima T, Hiramoto S, Baba T, Dacheux F, Dacheux JL, Sugita Y \& Jin Y 1999 A porcine homolog of the major secretory protein of human epididymis, HE1, specifically binds cholesterol. Biochimica et Biophysica Acta 1438 377-387. (doi:10.1016/S1388-1981(99)00070-0)

Pate BJ, White KL, Chen D, Aston KI, Sessions BR, Bunch TD \& Weimer BC 2008 A novel approach to identify bovine sperm membrane proteins that interact with receptors on the vitelline membrane of bovine oocytes. Molecular Reproduction and Development 75 641-649. (doi:10.1002/ mrd.20805)

Perez Martinez SL, Menendez-Helman RJ, Zitta KS, Brandelli A \& Miranda PV 2008 Characterization of human sperm N-acetylglucosaminidase. International Journal of Andrology 31 315-324. (doi:10.1111/ j.1365-2605.2007.00766.x)

Pervaiz S \& Brew K 1987 Homology and structure-function correlations between $\alpha 1$-acid glycoprotein and serum retinol-binding protein and its relatives. FASEB Journal 1 209-214.

Piñeiro $M$, Andrés $M$, Iturralde $M$, Carmona $S$, Hirvonen J, Pyörälä $S$, Heegaard PM, Tjornehoj K, Lampreave F, Piñeiro A et al. 2004 ITIH4 (inter- $\alpha$-trypsin inhibitor heavy chain 4 ) is a new acute-phase protein isolated from cattle during experimental infection. Infection and Immunity 72 3777-3782. (doi:10.1128/IAI.72.7.3777-3782.2004)

Souza AL, Castelo TS, Queiroz JP, Barros IO, Paula VV, Oliveira MF \& Silva AR 2009 Evaluation of anesthetic protocol for the collection of semen from captive collared peccaries (Tayassu tajacu) by electroejaculation. Animal Reproduction Science 116 370-375. (doi:10.1016/ j.anireprosci.2009.02.017)

Souza CE, Rego JP, Lobo CH, Oliveira JT, Nogueira FC, Domont GB, Fioramonte M, Gozzo FC, Moreno FB, Monteiro-Moreira AC et al. 2012 Proteomic analysis of the reproductive tract fluids from tropicallyadapted Santa Ines rams. Journal of Proteomics 75 4436-4456. (doi:10. 1016/j.jprot.2012.05.039)

Statistical Analysis Systems (SAS). SAS User's Guide. Cary, NC: Statistical Analysis Systems Institute Inc; 2003. 
Storey BT 1997 Biochemistry of the induction and prevention of lipoperoxidative damage in human spermatozoa. Molecular Human Reproduction 3 203-213. (doi:10.1093/molehr/3.3.203)

Talevi R \& Gualtieri R 2010 Molecules involved in sperm-oviduct adhesion and release. Theriogenology 73 796-801. (doi:10.1016/j.theriogenology.2009.07.005)

Tomomasa H, Waguri S, Umeda T, Koiso K, Kominami E \& Uchiyama Y 1994 Lysosomal cysteine proteinases in rat epididymis. Journal of Histochemistry and Cytochemistry 42 417-425. (doi:10.1177/42.3.8308258)

Topfer-Petersen E, Ekhlasi-Hundrieser M \& Tsolova M 2008 Glycobiology of fertilization in the pig. International Journal of Developmental Biology 52 717-736. (doi:10.1387/ijdb.072536et)

Vernet P, Rock E, Mazur A, Rayssiguier Y, Dufaure JP \& Drevet JR 1999 Selenium-independent epididymis-restricted glutathione peroxidase 5 protein (GPX5) can back up failing Se-dependent GPXs in mice subjected to selenium deficiency. Molecular Reproduction and Development 54 362-370. (doi:10.1002/(SICI)1098-2795(199912)54:4<362:: AID-MRD6>3.0.CO;2-)

Wakabayashi H, Matsumoto H, Hashimoto K, Teraguchi S, Takase M \& Hayasawa H 1999 Inhibition of iron/ascorbate induced lipid peroxidation by an $\mathrm{N}$-terminal peptide of bovine lactoferrin and its acylated derivatives. Bioscience, Biotechnology, and Biochemistry 63 955-957. (doi:10.1271/bbb.63.955)
Witkin SS, Richards JM, Bongiovanni AM \& Zelikovski G 1983 An IgG-FC binding protein in seminal fluid. American Journal of Reproductive Immunology 3 23-27. (doi:10.1111/j.1600-0897.1983.tb00207.x)

Xu W, Hu H, Wang Z, Chen X, Yang F, Zhu Z, Fang P, Dai J, Wang L, Shi H et al. 2012 Proteomic characteristics of spermatozoa in normozoospermic patients with infertility. Journal of Proteomics 75 5426-5436. (doi:10.1016/j.jprot.2012.06.021)

Zalata A, El-Samanoudy AZ, Shaalan D, El-Baiomy Y, Taymour M \& Mostafa T 2012 Seminal clusterin gene expression associated with seminal variables in fertile and in fertile men. Journal of Urology 188 1260-1264. (doi:10.1016/j.juro.2012.06.012)

Ziyyat A, Rubinstein E, Monier-Gavelle F, Barraud V, Kulski O, Prenant M, Boucheix C, Bomsel M \& Wolf JP 2006 CD9 controls the formation of clusters that contain tetraspanins and the integrin $\alpha 6 \beta 1$, which are involved in human and mouse gamete fusion. Journal of Cell Science 119 416-424. (doi:10.1242/jcs.02730)

Received 21 May 2013

First decision 8 July 2013

Revised manuscript received 4 February 2014

Accepted 10 February 2014 